\title{
PERSEPSI KONSUMEN TERHADAP PROSES PERSONAL SELLING DI PT TALENTS SPECTRUM CABANG DEPOK
}

\author{
${ }^{1)}$ Muhlis, ${ }^{2)}$ Ruswanto \\ ${ }^{1)}$ Dosen Program Studi Manajemen, STIE Dewantara Jl. Raya Pemda Bojong Depok Baru III, \\ Karadenan, Cibinong, Bogor, Jawa Barat 16913, Indonesia \\ Email: muhlis@dewantara.ac.id \\ ${ }^{2)}$ Alumni Program Studi Manajemen, STIE Dewantara \\ Jl. Raya Pemda Bojong Depok Baru III, Karadenan, Cibinong, Bogor, \\ Jawa Barat 16913, Indonesia \\ Email: ruswantoafif@gmail.com
}

\begin{abstract}
Personal selling is used in product marketing of PT. Talents Spectrum which is a form of direct communication between sales people who represent companies and potential customers. The object of research is consumers who buy the services of PT. Talents Spectrum Depok Branch. The purpose of this study was to determine consumer perceptions of the approach process, presentation stage, handle objections and closing sales in personal selling. Samples were taken using Slovin formula and analyzed using the Weighted Means Score (WMS). The results of the study showed that the entire process of personal selling carried out by the company's sales force had very good assessment criteria, with a value of 4.043. The process stage that has the smallest value is the presentation stage, with a value of 4.031. The smallest indicator of personal selling is self-introduction to the approach process with 3,917 and reconfirming the product explanation in the sales closing process with a value of 3,917.
\end{abstract}

Keywords: Personal Selling, Weighted Means Score, Fingger Print Analysis.

\begin{abstract}
ABSTRAK
Personal selling digunakan dalam pemasaran produk PT. Talents Spectrum yang merupakan bentuk komunikasi langsung antara tenaga penjual yang mewakili perusahaan dengan calon konsumen. Objek penelitan adalah konsumen yang membeli jasa PT. Talents Spectrum Cabang Depok.Tujuan penelitian ini adalah untuk mengetahui persepsi konsumen terhadap proses pendekatan, presentasi, menangani keberatan dan mentup penjualan dalam personal selling. Sampel diambil menggunakan rumus slovin dan dianalisis mengunakan Weighted Means Score (WMS). Hasil penelitian menunjukkan bahwa seluruh proses personal selling yang dilakukan oleh tenaga penjualan perusahaan memiliki kriteri penilaian yang sangat baik, dengan nilai 4,043. Tahapan proses yang memiliki nilai paling kecil adalah tahap presentasi, dengan nilai sebesar 4,031. Indikator dari personal selling yang paling kecil adalah pengenalan diri pada proses pendekatan dengan 3,917 dan mengkonfirmasi kembali penjelasan produk pada proses menutup penjualan dengan nilai 3,917.
\end{abstract}

Kata kunci: Personal Selling, Weighted Means Score, Analisis Sidik Jari.

\section{PENDAHULUAN \\ Personal selling merupakan bentuk} komunikasi langsung antara tenaga penjual yang mewakili perusahaan dengan calon konsumen. Teknik ini merupakan cara yang paling effektif untuk menanamkan pilihan, keyakinan dan tindakan pembeli pada tingkatan tertentu dalam proses pembelian (Shinta, 2011).
PT. Talent Spectrum merupakan salah satu perusahaan jasa yang bergerak dalam bidang analisis sidik jari. Produk yang dihasilkan diantaranya: 1 . dermatoghlypics intelegence capacity merupakan produk assessment berdasarkan analisis sidik jari untuk mengetahui potensi gaya belajar, motivasi dan multiple intelegence. 
produk ini sangat cocok untuk pengembangan dunia pendidikan dan masa kanak-kanak, dan 2. potential learning distribution merupakan produk yang menitikberatkan pada keperluan sekolah dalam mengetahui gaya belajar dan bakat siswanya. Produk ini juga memberikan referensi dalam pengambilan jurusan yang paling sesuai.

Pemasaran produk ini dilakukan melalui pendekatan personal selling, karena keunikan produk yang dijual sehingga calon konsumen memerlukan penjelasan yang bisa menguatkan untuk menggunakan produk tersebut.

Tujuan penelitian ini adalah:

1. Untuk mengetahui persepsi konsumen terhadap proses pendekatan dalam personal selling?

2. Untuk mengetahui persepsi konsumen terhadap proses presentasi dalam personal selling?

3. Untuk mengetahui persepsi konsumen terhadap proses menangani keberatan dalam personal selling?

4. Untuk mengetahui persepsi konsumen terhadap proses menutup penjualan dalam personal selling?

\section{TINJAUAN PUSTAKA}

Kotler dan Amstrong (2008) menerangkan bahwa personal selling adalah presentasi pribadi oleh para tenaga penjual perusahaan dalam rangka mencapai target penjualan dan membangun hubungan antara perusahaan dan pelanggan.

Walker (1997) menerangkan bahwa tujuan personal selling adalah

1. Penerimaan produk baru oleh pelanggan,

2. Mendapatkan pelanggan baru,

3. Mempertahankan loyalitas pelanggan

4. Mempersiapkan penjualan yang akan datang,
5. Melengkapi penjualan yang akan datang dengan mengkomunikasikan informasi produk, dan

6. Mendapat informasi pasar.

Tahapan proses dalam personal selling menurut Kotler dan Amstrong (2008) adalah sebagai berikut:

\section{a. Pendekatan}

Yaitu proses personal selling dimana tenaga penjual bertemu dan menyapa calon konsumen untuk mendapatkan hubungan untuk memulai suatu awal yang baik. Langkah ini melibatkan penampilan tenaga penjual, kata-kata pembukaan, dan penjelasan lanjut. Mc Daniel (2001) mengatakan bahwa "konsumen lebih mengingat bagaimana tenaga penjual menampilkan diri dibandingkan dengan apa yang tenaga penjual katakan". Oleh sebab itu, penting bagi tenaga penjual untuk memberikan kesan pertama yang baik kepada calon konsumen.

b. Presentasi

Yaitu proses personal selling dimana tenaga penjual menjelaskan produk kepada calon konsumen, menunjukkan bagaimana produk akan menghasilkan penghemat uang bagi pembeli. Tenaga penjual menjelaskan fitur-fitur kepada calon konsumen menggunakan pendekatan kepuasan kebutuhan, wiraniaga mulai dengan pencarian kebutuhan pelanggan banyak berbicara. Untuk itu tenaga penjual harus mempunyai kemampuan mendengarkan dan memecahkan masalah dengan baik.

c. Mengatasi Keberatan

Yaitu proses personal selling dimana tenaga penjual melakukan proses peyelidikan, pengklarifikasian dan mengatasi keberatan konsumen. Selama presentasi, konsumen hampir selalu mempunyai keberatan. Demikian juga sewaktu diminta untuk menuliskan pesanan. Masalahnya bisa logis, bisa juga psikologis, dan keberatan saling tidak diungkapkan keluar. 
Dalam mengatasi keberatan, tenaga penjual harus menggunakan pendekatan positif, menggali keberatan yang tersembunyi, meminta konsumen untuk menjelaskan keberatan. Keberatan konsumen digunakan untuk memberikan informasi yang lebih banyak dan digunakan sebagai alasan agar konsumen menggunakan produk yang ditawarkan. Setiap tenaga penjualan membutuhkan pelatihan dalam keterampilan mengatasi masalah.

d. Menutup Penjualan

Yaitu proses personal selling dimana tenaga penjual menanyakan apa yang hendak dipesan oleh konsumen. Setelah dapat mengatasi keberatan tenaga penjual dapat mencoba menutup penjualan. Tenaga penjual harus dapat mengetahui tanda-tanda penutupan dari konsumen termasuk gerakan fisik, komentar dan pertanyaan. Sebagai contoh, pelanggan mungkin duduk condong ke depan dan mengangguk menyetujui atau menanyakan harga dan syarat pembayaran kredit.

\subsection{Kerangka Pemikiran}

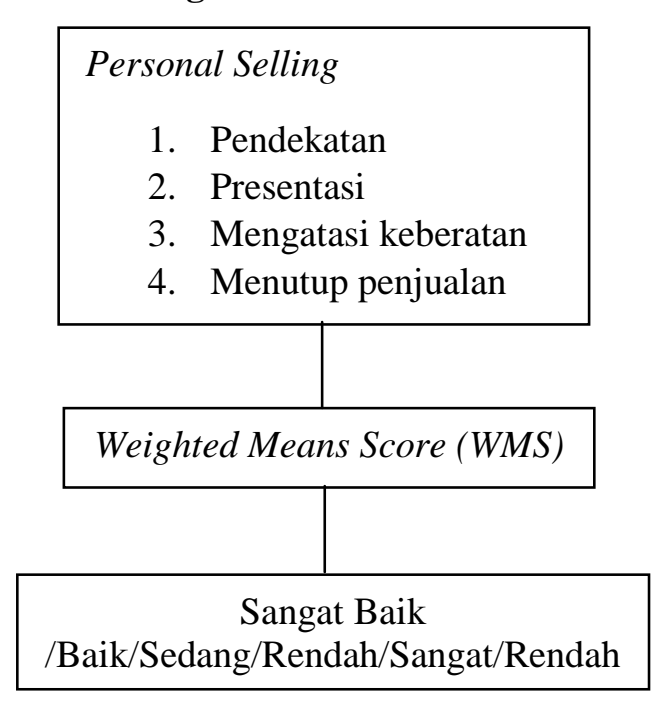

Gambar 1. Kerangka Pemikiran
Penelitian

\section{METODE PENELITIAN}

Dalam penelitian ini populasi yang digunakan adalah seluruh konsumen yang membeli jasa di Talents Spectrum Depok dengan jumlah 2.580 orang. (Kurun waktu Januari s.d. Desember 2017).

Jumlah sampel yang digunakan berdasarkan rumus slovin sebanyak 97 konsumen dengan kriteria melakukan pembelian jasa di Telants Spectrum Depok. Tingkat kepercayaan yang digunakan sebesar $90 \%$.

Teknik pengambilan sampel dilakukan dengan accidental sampling yaitu teknk pengambilan sampel berdasarkan pada saat tersebut, siapa saja yang kebetulan bertemu dengan peneliti dapat digunakan sebagai sampel jika responden dipandang sesuai sebagai sumber data. Data dianalisis menggunakan uji validitas, uji realibilitas dan Weighted Means Score (WMS).

Teknik WMS digunakan untuk mendapatkan kecenderungan skor yang diberikan oleh responden pada setiap item pertanyaan sesuai dengan kriteria yang digunakan. Kriteia pengambilan keputusan dalam WMS dapat dilihat pada Tabel 1.

\section{Tabel 1. Kriteria Penilaian}

\begin{tabular}{|l|c|}
\hline Rentang Penilaian & Kriteria \\
\hline Sangat Baik & $5,000-4,201$ \\
\hline Baik & $4,200-3,401$ \\
\hline Cukup & $3,400-2,601$ \\
\hline Rendah & $2,600-1,801$ \\
\hline Sangat Rendah & $1,800-1,000$ \\
\hline
\end{tabular}


4. HASIL DAN PEMBAHASAN

\subsection{Uji Validitas}

Tabel 2. Hasil Uji Validitas

\begin{tabular}{|l|c|c|c|}
\hline \multicolumn{1}{|c|}{ Indikator } & $\mathbf{r}_{\text {hitung }}$ & $\mathbf{r}_{\text {tabel }}$ & Ket \\
\hline Pendekatan & & & \\
Indikator 1 & 0.497 & 0.166 & Valid \\
Indikator 2 & 0.236 & 0.166 & Valid \\
Indikator 3 & 0.383 & 0.166 & Valid \\
\hline Presentasi & & & \\
Indikator 1 & 0.435 & 0.166 & Valid \\
Indikator 2 & 0.342 & 0.166 & Valid \\
Indikator 3 & 0.358 & 0.166 & Valid \\
& & & \\
\hline Menangani & & & \\
Keberatan & & & \\
Indikator 1 & 0.390 & 0.166 & Valid \\
Indikator 2 & 0.295 & 0.166 & Valid \\
Indikator 3 & 0.412 & 0.166 & Valid \\
\hline Menutup & & & \\
Penjualan & & & \\
Indikator 1 & 0.449 & 0.166 & Valid \\
Indikator 2 & 0.342 & 0.166 & Valid \\
Indikator 3 & 0.395 & 0.166 & Valid \\
& & & \\
\hline
\end{tabular}

Sumber: data diolah (2018)

Tabel di atas menunjukkan bahwa semua item pernyataan yang digunakan untuk mengukur variabel-variabel yang digunakan dalam penelitian ini mempunyai koefisien korelasi yang lebih besar dari $r_{\text {tabel}}$. Untuk sampel sebanyak 97 orang dengan toleransi sebesar $10 \%$ yaitu 0.1663 . Dari hasil tersebut menunjukkan bahwa semua item pernyataan (indikator) adalah valid.

\subsection{Realibilitas}

Tabel 3. Hasil Uji Reabilitas

\begin{tabular}{|l|c|c|}
\hline \multicolumn{1}{|c|}{ Indikator } & $\boldsymbol{\alpha}$ & Keterangan \\
\hline Pendekatan & & \\
Indikator 1 & 0.750 & Realibel \\
Indikator 2 & 0.772 & Realibel \\
Indikator 3 & 0.760 & Realibel \\
& & \\
\hline Presentasi & & \\
Indikator 1 & 0.755 & Realibel \\
Indikator 2 & 0.763 & Realibel \\
Indikator 3 & 0.761 & Realibel \\
& & \\
\hline Menangani & & \\
Keberatan & & \\
Indikator 1 & 0.759 & Realibel \\
Indikator 2 & 0.767 & Realibel \\
Indikator 3 & 0.757 & Realibel \\
\hline Menutup & & \\
Penjualan & & \\
Indikator 1 & 0.754 & Realibel \\
Indikator 2 & 0.763 & Realibel \\
Indikator 3 & 0.759 & Realibel \\
\hline Sumber: data dion
\end{tabular}

Sumber: data diolah (2018)

Reliabilitas diukur dengan alpha cronbach. Jika nilai alpha di atas 0,60 maka dikatakan bahwa instrumen tersebut adalah reliabel. Hasil uji realibilitas menunjukkan bahwa semua nilai alpha cronbach's lebih besar dari 0,60 berarti instrumen tersebut dinyatakan reliabel.

\subsection{Karakteristik Responden}

Tabel 4. Karakteristik Responden Berdasarkan Jenis Kelamin

\begin{tabular}{|c|c|c|}
\hline Jenis Kelamin & Responden & Persen \\
\hline Laki-Laki & 24 & 24,8 \\
\hline Perempuan & 73 & 75,2 \\
\hline Total & 97 & 100 \\
\hline
\end{tabular}

Sumber: data diolah (2018)

Dari tabel 4. dapat dilihat berdasarkan jenis kelamin, responden terdiri dari 24 orang atau $24,8 \%$ berjenis kelamin laki-laki dan 73 orang atau $75,2 \%$ berjenis kelamin perempuan. 
Tabel 5. Karakteristik Responden Berdasarkan Usia

\begin{tabular}{|c|c|c|}
\hline Usia & Responden & Persen \\
\hline $17-22$ & 6 & 6,2 \\
\hline $23-28$ & 15 & 15,5 \\
\hline $29-34$ & 36 & 37,1 \\
\hline$>34$ & 40 & 41,2 \\
\hline Total & 97 & 100 \\
\hline
\end{tabular}

Sumber: data diolah (2018)

Tabel 5. menunjukkan bahwa responden berdasarkan usia yang berumur >34 tahun merupakan yang paling banyak, yaitu 40 orang atau $41,2 \%$ dan yang paling sedikit berumur di 17-22 tahun, yaitu terdiri dari 6 orang atau $6,2 \%$.

Tabel 6. Karakteristik Responden Berdasarkan Pendidikan

\begin{tabular}{|c|c|c|}
\hline Pendidikan & Responden & Persen \\
\hline SMU & 58 & 59,8 \\
\hline Diploma & 6 & 6,2 \\
\hline S1 & 28 & 28,9 \\
\hline S2 & 5 & 5,1 \\
\hline S3 & 0 & 0 \\
\hline Total & 97 & 100 \\
\hline
\end{tabular}

Sumber: data diolah (2018)

Tabel 6. menunjukkan bahwa responden berdasarkan pendidikan yang terbanyak adalah responden yang berpendidikan SMU Sebanyak 58 orang atau $59,8 \%$, S1 sebanyak 28 orang atau 28,9\%, Diploma 6 orang atau $6,2 \%$ dan S2 sebanyak 5 orang atau $5,1 \%$.

Tabel 7. Karakteristik responden berdasarkan jenis pekerjaan

\begin{tabular}{|c|c|c|}
\hline Pekerjaan & Responden & Persen \\
\hline Swasta & 67 & 69,1 \\
\hline PNS & 9 & 9,3 \\
\hline Wiraswasta & 8 & 8,2 \\
\hline Lainnya & 13 & 13,4 \\
\hline Total & 97 & 100 \\
\hline
\end{tabular}

Sumber: data diolah (2018)
Tabel 7. dapat dilihat berdasarkan pekerjaan, responden yang paling dominan adalah pegawai swasta yang terdiri dari 67 orang atau $69,1 \%$, diikuti pekerjaan lainnya sebanyak 13 orang atau $13,4 \%$, selanjutnya pegawai negeri sebanyak 9 orang, dan wiraswasta sebanyak 8 orang.

\subsection{Persepsi Konsumen Terhadap Proses Pendekatan dalam Personal Selling}

Tabel 8. Persepsi Konsumen Proses Pendekatan

\begin{tabular}{|l|c|c|}
\hline \multicolumn{1}{|c|}{ Indikator } & $\begin{array}{c}\text { Angka } \\
\text { Penafsiran }\end{array}$ & $\begin{array}{c}\text { Kriteria } \\
\text { Penilaian }\end{array}$ \\
\hline $\begin{array}{l}\text { Penampilan } \\
\text { rapi }\end{array}$ & 4,062 & Baik \\
\hline $\begin{array}{l}\text { Mengenalkan } \\
\text { identitas diri }\end{array}$ & 3,917 & Baik \\
\hline $\begin{array}{l}\text { Sikap ramah } \\
\text { dalam menyapa } \\
\text { konsumen }\end{array}$ & 4,185 & Baik \\
\hline \multicolumn{1}{|c|}{ Rata-rata } & 4,055 & Baik \\
\hline
\end{tabular}

Sumber: data diolah (2018)

Proses pendekatan dalam melakukan penjualan yang dilakukan oleh tenaga penjual perusahaan memiliki nilai 4,055 yang berarti baik. Proses pendekatan dalam suatu proses penjualan merupakan langkah awal dalam menjual suatu produk.

Proses ini merupakan suatu proses awal dengan waktu yang sangat singkat, tetapi memiliki nilai urgensi yang sangat penting. Dalam tahap ini kesan pertama perusahaan yang diwakili oleh tenaga penjualnya harus dapat ditangkap yang baik oleh calon kosumen. Kegagalan dalam proses ini merupakan kehilangan calon-calon konsumen potensial dan tidak terjadi penyampaian informasi produk pada tahapan-tahapan personal selling.

4.5 Persepsi Konsumen Terhadap Proses Presentasi dalam Personal Selling 
Tabel 9. Persepsi Konsumen Proses Presentasi

\begin{tabular}{|l|c|c|}
\hline \multicolumn{1}{|c|}{ Indikator } & $\begin{array}{c}\text { Angka } \\
\text { Penafsiran }\end{array}$ & $\begin{array}{c}\text { Kriteria } \\
\text { Penilaian }\end{array}$ \\
\hline $\begin{array}{l}\text { Bahasa yang } \\
\text { digunakan } \\
\text { mudah } \\
\text { dimengerti }\end{array}$ & 4,021 & Baik \\
\hline $\begin{array}{l}\text { Menguasai dan } \\
\text { memahami } \\
\text { produk }\end{array}$ & 3,928 & Baik \\
\hline $\begin{array}{l}\text { Menjelaskan } \\
\text { secara rinci } \\
\text { produk }\end{array}$ & 4,144 & Baik \\
\hline \multicolumn{1}{|c|}{ Rata-rata } & 4,031 & Baik \\
\hline
\end{tabular}

Sumber: data diolah (2018)

Proses presentasi dalam melakukan penjualan yang dilakukan oleh tenaga penjual perusahaan memiliki nilai 4,031 yang berarti baik. Tahap presentasi merupakan penyempaian informasi produk kepada konsumen yang disampaikan oleh tenaga penjualan perusahaan.

Penyampaian informasi harus dapat terinformasikan secara menyeluruh dan tidak terdapat perbedaan persepsi antara tenaga penjual dan konsumen, sehingga dalam proses persentasi harus menggunakan bahasa yang mudah dimengerti dan dijelaskan secara rinci. Dalam menjelaskan informasi tersebut para tenaga penjual harus menguasi tentang keseluruhan informasi produk yang akan ditawarkan.

Bonne dan Kurtz menyebutkan bahwa tahapan presentasi atau demonstrasi, tenaga penjualan harus memberikan pesan-pesan promosi. Biasanya menjelaskan fiturfitur penting dan keunggulan dari produknya. Oleh karena itu, pada saat presentasi tenaga penjual harus dipersiapkan secara baik, dilatih secara berulang materi yang akan dikatakan, menggunakan kontak mata langsung, bertanya dengan pertanyaan terbuka dan bersikap tenang, (Mc Daniel, 2001).

\subsection{Persepsi KonsumenTerhadap Proses Menangani Keberatan dalam Personal Selling}

Tabel 10 . Persepsi Konsumen Proses Menangani Keberataan

\begin{tabular}{|l|c|c|}
\hline \multicolumn{1}{|c|}{ Indikator } & $\begin{array}{c}\text { Angka } \\
\text { Penafsiran }\end{array}$ & $\begin{array}{c}\text { Kriteria } \\
\text { Penilaian }\end{array}$ \\
\hline $\begin{array}{l}\text { Menanyakan } \\
\text { keberatan yang } \\
\text { dirasakan } \\
\text { pengguna } \\
\text { produk }\end{array}$ & 4,031 & Baik \\
\hline $\begin{array}{l}\text { Berempati } \\
\text { dalam } \\
\text { menanggapi } \\
\text { keberatan }\end{array}$ & 4,021 & Baik \\
\hline $\begin{array}{l}\text { Menjawab } \\
\text { keberatan }\end{array}$ & 4,051 & Baik \\
\hline \multicolumn{1}{|c|}{ Rata-rata } & 4,034 & Baik \\
\hline
\end{tabular}

Sumber: data diolah (2018)

Proses menangani keberatan dalam melakukan penjualan yang dilakukan oleh tenaga penjual perusahaan memiliki nilai 4,034 yang berarti baik.

Boone dan Kurtz (2002) mengatakan bahwa penanganan keberatan secara tepat akan memberikan kesepatan untuk tenaga penjualan menghilangkan hambatan dan mewujudkan penjualan. Langkah ini bisa berubah menjadi tahap positif dari proses penjualan karena memberikan peluang kepada tenaga penjualan untuk memberikan informasi tambahan dan menawarkan solusi yang unik sebagai salah satu cara untuk mengklarifikasi keberatan-keberatan yang muncul. Lancaster (1990) menyatakan pendekatan yang tepat untuk menangani keberatan adalah dengarkan dengan seksama, penuh perhatian dan menghargai. 
4.7 Persepsi Konsumen Terhadap Proses Menutup Penjualan dalam Personal Selling

Tabel 11. Persepsi Konsumen Proses Menutup Penjualan

\begin{tabular}{|l|c|c|}
\hline \multicolumn{1}{|c|}{ Indikator } & $\begin{array}{c}\text { Angka } \\
\text { Penafsiran }\end{array}$ & $\begin{array}{c}\text { Kriteria } \\
\text { Penilaian }\end{array}$ \\
\hline $\begin{array}{l}\text { Tidak memaksa } \\
\text { dalam } \\
\text { menanyakan } \\
\text { produk yang } \\
\text { akan di beli }\end{array}$ & 4,031 & Baik \\
\hline $\begin{array}{l}\text { Mengkonfirmasi } \\
\text { kembali } \\
\text { penjelasan } \\
\text { produk }\end{array}$ & 3,917 & Baik \\
\hline $\begin{array}{l}\text { Memberikan } \\
\text { referensi tentang } \\
\text { produk yang } \\
\text { sesuai }\end{array}$ & 4,206 & Sangat \\
\hline \multicolumn{1}{|c|}{ Rata-rata } & 4,051 & Baik \\
\hline
\end{tabular}

Sumber: data diolah (2018)

Proses penutupan penjualan yang dilakukan oleh tenaga penjualan memiliki nilai 4,051 yang berarti baik. Penutupan proses pada personal selling dilakukan dengan menanyakan produk yang akan dibeli, mengkonfirmasi apakah penjelasan pada tahap sebelumnya sudah jelas dan memberikan rekomendasi produk yang sesuai dengn kebutuhn konsumen. Penutupan penjualan yang diharapkan adalah terjadinya transaksi dimana konsumen paham akan produk yang ditawarkan adalah produk yang dibutuhkan oleh konsumen tersebut.

\subsection{Persepsi Konsumen Terhadap Proses Personal Selling}

Secara menyeluruh proses personal selling yang dilakukan oleh tenaga penjualan perusahaan sudah baik dengan nilai 4,043 (Tabel 11). Pencapaian nilai tahapan proses personal selling tercapai secara merata antara 4,031-4,055. Bila dilihat dari nilai yang terkecil maka presentasi memiliki nilai terkecil, sehingga untuk meningkatkan hasil yang lebih maksimal maka perlu dilakukan pelatihanpelatihan bagaimana melakukan persentasi yang baik

Tabel 11. Persepsi Konsumen Proses Personal Selling

\begin{tabular}{|l|c|c|}
\hline \multicolumn{1}{|c|}{ Variabel } & $\begin{array}{c}\text { Angka } \\
\text { Penafsiran }\end{array}$ & $\begin{array}{c}\text { Kriteria } \\
\text { Penilaian }\end{array}$ \\
\hline Pendekatan & 4,055 & Baik \\
\hline Presentasi & 4,031 & Baik \\
\hline $\begin{array}{l}\text { Menangani } \\
\text { keberatan }\end{array}$ & 4,034 & Baik \\
\hline $\begin{array}{l}\text { Menutup } \\
\text { penjualan }\end{array}$ & 4,051 & Baik \\
\hline \multicolumn{1}{|c|}{ Rata-rata } & 4,043 & Baik \\
\hline
\end{tabular}

Sumber: data diolah (2018)

Presentasi yang baik adalah perpaduan antara teknik komunikasi dan pemahaman isi persentasi. Isi presentasi adalah pemahaman materi produk yang akan dipersentasikan. Setelah dipahami kedua hal tersebut oleh tenaga penjual maka diperlukan latihan-latihan yang berulang sehingga tenaga penjual dapat beradaptasi di semua kondisi presentasi.

Presentasi yang baik pada dasarnya merupakan bagaimana melakukan komunikasi yang baik agar tidak ada pengurangan dalam menyampaikan pesan dan pesan dapat diterima dengan jelas. Dalam komunkasi yang baik diperlulukan kemampan dalam berbicara yang effektif.

Sameto (2000), menyatakan berbicara efektif merupakan sarana penyampaian ide kepada orang atau khalayak secara lisan dengan cara yang mudah dicerna dan dimengerti oleh pendengarnya. Hal ini memberikan penjelasan bahwa yang disebut dengan berbicara efektif adalah suatu langkah yang dilakukan pembicara untuk menyampaikan pendapat atau informasi dengan cara-cara tertentu sehingga pendengar dapat dengan mudah dimengerti tentang maksud dari informasi yang disampaikan.

Secara umum dasar-dasar berbicara efektif terdiri dari: pembukaan, isi/inti pembicaraan, dan penutup. Berbicara 
efektif merupakan cara-cara penyampaian pesan yang dilakukan dengan sistematis, benar, tepat, dan tidak berbelit-belit. Informasi disampaikan secara sederhana mungkin dan menggunakan tingkat bahasa yang disesuaikan dengan latar belakang pendengar. Jangan menggunakan bahasa dengan istilah yang terlalu tinggi untuk pendengar yang memiliki latar belakang pendidikan bawah. Hal ini akan membuat pendengar tidak dapat memahami informasi yang disampaikan.

Kelebihan dan kelemahan presentasi Triwidodo dan Kristanto (2004), mendefinisikan kelebihan presentasi antara lain sebagai berikut :

1. Umpan balik langsung, yang dimaksud umpan balik adalah masukan-masukan yang disampaikan oleh pendengar kepada pembicara. Umpan balik dari pendengar ini mungkin saja diperoleh saat presentasi sedang berlangsung, misalnya tepuk tangan atau gelak tawa pendengar karena tertarik dengan penjelasan pembicara atau kejenuhan pendengar terhadap penyampaian pembicara.

2. Kesempatan untuk menampilkan pribadi saat seorang pembicara diundang untuk melakukan presentasi, karena pada saat tersebut merupakan kesempatan dalam memperkenalkan diri dan kemampuan yang dimiliki.

3. Mempunyai pengaruh lebih kuat terhadap pendengar. Presentasi yang sukses akan membawa pengaruh yang lebih kuat kepada pendengarnya. Presentasi memiliki kekuatan lebih daripada sekadar laporan tertulis.

Sedangkan kelemahan dalam presentasi antara lain:

1. Bagi presentasi yang kurang persiapan akan berlangsung menjemukan dan akan meninggalkan kesan kurang baik bagi pendengar. Berbeda dalam pada laporan tertulis, sebab pada laporan tertulis dapat saja diatur naskahnya agar tampil rapi tanpa merepotkan orang lain. Pada saat presentasi apabila seorang pembicara yang selalu meralat ucapannya, maka pendengar akan diragukan kemampuan pembicara.

2. Saran dan kritik tidak dapat langsung diutarakan saat pembicara menyampaikan presentasinya, pendengar tidak dapat menyelingi pembicaraannya. Pendengar harus menampung segala pertanyaan atau sanggahan sampai pembicara selesai menyampaikan presentasinya. Sanggahan, kritik, dan saran hanya dapat dilakukan saat sesi tanya jawab berlangsung.

3. Kurang dapat diatur, presentasi melibatkan banyak hal terutama pendengar dengan jumlah banyak. Sementara itu, pendengar terdiri dari bermacam karakter dan watak. Dengan begitu pembicara harus mempunyai kemampuan tertentu untuk dapat mengambil kendali atas segala kemungkinan yang dapat terjadi sebagai akibat atas keberagaman pendengar ini.

Dengan adanya kelebihan dan kekurangan dari presentasi dalam proses personal salling, maka para tenaga penjualan PT. Talent Spectrum perlu melakukan persiapan sebelum melakukan presentasi produk. Purwanto (2003) menerangkan beberapa persiapan dasar yang dilakukan untuk mempersiapkan presentasi bisnis yang baik, antara lain:

1. Penguasaan terhadap topik atau materi yang akan dipresentasikan. Sebelum melakukan presentasi hendaknya pembicara telah menguasai materi yang akan disampaikan agar apa yang akan disampaikan dapat dimengerti oleh pendengar. Pembicara yang tidak menguasai materi tidak hanya akan membingungkan pendengar tetapi juga akan memberikan image yang kurang baik terhadap pembicara tersebut. 
2. Penguasaan berbagai alat bantu presentasi dengan baik dan benar. Untuk dapat menyajikan presentasi yang menarik dibutuhkan beberapa alat bantu presentasi. Penguasaan terhadap beberapa alat bantu ini akan sangat membantu pembicara dalam menyampaikan materi sehingga pendengar dapat lebih mengingat isi presentasi.

3. Menganalisis siapa pendengar anda. Pembicara dapat melakukan pendekatan terhadap pendengar dengan menggunakan kata tanya seperti: apa, siapa, di mana, kapan, mengapa, dan bagaimanan, maka pembicara dapat mengetahui dan menganalisa siapa pendengar yang hadir dan dapat menentukan pendekatan yang tepat dalam penyampaian presentasi.

4. Menganalisis berbagai lingkungan, lokasi, atau tempat untuk presentasi. Hendaknya pembicara mengenali lokasi tempat berlangsungnya presentasi sebelum acara berlangsung. Hal ini dilakukan untuk mempermudah pembicara menentukan alat bantu presentasi yang sesuai dan memperkirakan jumlah pendengar sehingga pembicara mendapatkan cukup gambaran dalam melakukan persiapan yang lebih matang.

Sameto (2000), menyebutkan dalam membuat persiapan, dapat menggunakan patokan sebagai berikut :

1. Survey,

2. Analisis,

3. Rencana/Bagan,

4. Aktualisasi/Realisasi,

5. Pencatatan dan Evaluasi.

Menurut Kasali (2006), tips bagaimana melakukan presentasi yang baik yaitu:

1. Jangan membiasakan diri tergantung pada teks. Teks dapat membunuh bakat, merusak flow (irama), dan menciptakan jarak antara pembicara dengan pendengar. Gunakan pointers, sekedar untuk membantu anda.

2. Ukur secara sungguh-sungguh dalamnya sungai. Pelajari dulu siapa pendengar anda, misalnya mengenai latar belakang, jalan pikiran, pendidikan, dan jabatan mereka.

3. Jangan bicarakan hal yang sudah mereka ketahui, atau yang tak ingin mereka dengar. Selalu sajikan hal-hal yang orisinal, jangan merusak mood pendengar dengan pernyataan yang tidak mereka sukai.

4. Jangan biarkan pendengar jenuh. Jaga volume suara dan jaga nada agar tidak monoton. Begitu mereka mulai jenuh, ajaklah berdialog, sampaikan sedikit humor.

5. Humor yang digunakan tidak perlu berlebihan. Ia hanya boleh digunakan untuk membangkitkan daya pikir.

6. Periksa ruangan dan fasilitas presentasi termasuk mikrofon sebelum presentasi dimulai.

7. Biasakan interaktif, jangan asik bicara sendiri. Berikan kesempatan kepada peserta untuk memberikan contoh, jawaban, melakukan aktivitas tertentu, tertawa, atau bahkan mendengarkan musik.

8. Be specific, salalu berikan contoh dan ilustrasi. Sesekali berikan cerita.

9. Jangan merendahkan mutu dengan mengatakan "Maaf sebenarnya saya tidak siap", dan nada merendah lainnya. Manusia adalah makhluk malas yang hanya mau mendengarkan orang yang layak ia dengar dan ia anggap lebih tahu.

10. Latihan yang cukup. Selalu mintalah umpan balik. Bila perlu rekam, putar kembali, minta pendapat dari orang dekat.

11. Perhatikan bahasa tubuh. Jangan melakukan gerakan yang merusak penampilan. 
12. Berpakaianlah agak cerah agar anda menciptakan kesegaran di dalam ruangan.

13. Jangan berbicara seperti sedang ngobrol dengan seseorang. Ingatlah anda berbicara di hadapan puluhan orang, kombinasikan bahasa resmi dengan bahasa percakapan yang layak.

Tenaga penjualan biasanya sebelum melakukan presentasi sering mengalami gugup/demam panggung. Tenaga penjualan yang sudah handal maupun yang sudah berpengalaman terkadang masih mengamali hal ini. Kejadian ini terjadi karena pendengar yang dihadapi memiliki karakter yang berbeda beda, sehingga perlu terus dilakukan dan latihan. Setiap tenaga penjual dalam melakukan presentasi memiliki cara dalam mengatasi gugup.

Menurut Suhardjono

memberikan cara mengurangi demam panggung, yaitu :

1. Tingkatkan percaya diri

2. Jangan berlebihan menilai negatif para pendengar

3. Pada setiap awal lakukan gerakangerakan untuk mengalihkan rasa gemetar

4. Persiapkan catatan kecil tentang halhal pokok dari topik yang akan dibicarakan. Jangan berupaya menghafalkan apa yang akan disajikan.

Dalam menyampaikan isi presentasi tenaga penjualan perlu memiliki kemampuan dalam menyusun kata demi kata agar penyampaian pesan dapat tersampaikan secara baik dan menyeluruh. Darmastuti (2007) mengemukakan kiat-kiat yang dapat dilakukan supaya pesan yang dikirim dapat mengenai sasaran :

1. Pesan harus dirancang sedemikian rupa agar sesuai dengan pendengar yang menerimanya.

2. Pesan harus menggunakan lambinglambang yang dimengerti oleh pembicara dan pendengar, sehingga menimbulkan persepsi yang sama diantara kedua belah pihak.

3. Pesan yang disampaikan oleh pembicara dapat memenuhi kebutuhan pendengar serta memberikan saran.

4. Pesan yang disampaikan oleh pembicara merupakan suatu saran yang dapat memberikan suatu solusi atau jalan keluar.

Kemampuan lain yang harus dimiliki dan di latih oleh tenaga penjuala dalam presentasi adalah kemampuan dalam menjawab atas pertanyaan atau sangahan. Pertanyaan atau sanggahan merupakan sinyal yang penting karena pendengar menyimak isi presentasi. Pertanyaaan dan sanggahan merupakan bentuk dalam memngkonfirmasi ulang dari isi presentasi. Pentingnya moment ini dalam suatu rangkaian personal selling, maka tenaga penjualan perlu dilatih dalam menjawab pertanyaan atau sanggahan.

Suhardjono (1994) menyebutkan strategi dalam menjawab pertanyaan:

1. Terhadap peserta yang merasa superior, arahkan padanya agar juga mendengarkan pendapat orang lain yang dapat dipakai sebagai alternatif.

2. Kepada peserta yang selalu ingin menang, anda jangan terpancing dalam perdebatan.

3. Untuk peserta yang banyak omong dan cenderung mendominasi pembicaraan, perlu penegasan anda untuk memotong pembicaraan tanpa menyakitkan perasaannya.

Dengan ditingkatkan kemampuan tenaga penjualan dalam presentasi, maka personal selling PT Talent Spectrum akan dapat meningkat. Nilai presentasi yang merupakan nilai tekecil dari proses personal selling sehingga bila proses ini dilakukan perbaikan dengan cara peningkatan kemampuan presentasi akan dapat meningkatkan penjualan PT Talent Spectrum. 


\section{KESIMPULAN DAN SARAN}

\subsection{Kesimpulan}

Hasil penelitian dapat disimpulkan sebagai berikut:

1. Dilihat dari seluruh proses personal selling yang dilakukan oleh tenaga penjualan perusahaan memiliki kriteria penilain yang baik, dengan nilai 4,043

2. Tahapan proses yang memiliki nilai paling kecil adalah tahap presentasi, dengan nilai sebesar 4,031.

3. Indikator dari personal selling yang paling kecil adalah pengenalan diri pada proses pendekatan dengan nilai 3,917 dan mengkonfirmasi kembali penjelasan produk pada proses menutup penjualan dengan nilai 3,917 .

\subsection{Saran}

Hasil penelitian dapat disarankan sebagai berikut:

1. Perlu dilakukan pelatihan teknik presentasi untuk tenaga penjualan agar memiliki kemampuan presentasi dalam kondisi apapun.

2. Perlu dilakukan pelatihan komunikasi seperti teknik pengenalan diri, karena pengenalan diri tenaga penjual merupakan perwakilan pengenalan dari perusahaan.

\section{DAFTAR PUSTAKA}

Boone, Louis E dan Kurtz, David L. 2002. Pengantar Bisnis. Jilid ke-1. Terjemahan Anwar Fadriansyah. Penerbit Erlangga. Jakarta.

Darmastuti. Rini 2007. Etika PR dan E-PR. Gramedia. Yogyakarta.

Lancaster, Geoffrey \& Jobber, David. 1990. Teknik dan Manajemen Penjualan, Binarupa Aksara, Jakarta.

Kasali Rhenald. 2006. Sukses Melakukan Presentasi. Gramedia. Jakarta.
Kotler Philip dan Armstrong. 2008. Prinsipprinsip Pemasaran. Jilid I. Erlanga. Jakarta.

Mc Daniel, Lamb Hair. 2001. Pemasaran, Jilid 2. PT Salemba Emban Patria, Jakarta.

Purwanto Djoko. 2003. Komunikasi Bisnis. Erlangga. Jakarta.

Shinta, Agustina. 2011. Manajemen Pemasaran. Universitas Brawijaya Press.

Sugiyono. 2003. Metode Penelitian. Alfabeta. Bandung

Suhardjono. 1994. Meningkatkan Kemampuan Berkomunikasi. ITN Press. Malang.

Sameto. Hudoro. 2000. Cara Berbicara atau Presentasi dengan Audio-Visual. Jakarta:Gramedia.

Triwidodo Titik dan Kristanto. Djoko. 2004. Pengembangan Kepribadian Sekretaris. Gramedia. Jakarta.

Walker, Boyd L. 1997. Manajemen Pemasaran, Jilid 1. Alih Bahasa Oleh Imam Nurmawan. Erlangga. Jakarta. 